\title{
Teaching Civic Engagement Globally: Spreading the Word
}

\section{ELIZABETH C. MATTO | ASSOCIATE RESEARCH PROFESSOR AT EAGLETON INSTITUTE OF POLITICS, RUTGERS UNIVERSITY}

ducators around the globe are facing challenges in teaching democracy in an era in which populist values are on the rise, authoritarian governance is legitimized, and core democratic tenets are regularly undermined by leaders and citizens alike. With the recent publication of Teaching Civic Engagement Globally, the American Political Science Association continues to advance the scholarship of civic engagement education. To kick off the book launch, the Eagleton Institute of Politics and the American Political Science Association hosted an international virtual conversation with editors and contributors to the new book discussing the need to teach democratic citizenship, the theoretical discussions and challenges regarding global civic engagement education, and successful evidence-based pedagogical approaches for linking democratic education research with action that reflects contemporary global circumstances.

Teaching Civic Engagement Globally builds upon two previous publications on democracy learning and engagement. Teaching Civic Engagement: From Student to Active Citizen (2013) offers political scientists a range of models of civic engagement pedagogy from a variety of sub-disciplines that suit diverse teaching styles, students, and institutions. In Teaching Civic Engagement Across the Disciplines (2017), contributors broadened the range of civic learning models beyond political science to include such disciplines as English, civil engineering, and even the arts. Indeed, teaching democratic citizenship requires educators of all disciplines to embrace the value of civic learning and for campuses to integrate democratic learning and engagement into its campus culture.

Educators across the world face similar concerns and challenges about the state of education for democracy and a shared sense of urgency to develop quality civic engagement education for today's students. No one country has a monopoly on these concerns, the need for more options, or the solutions. Further, as higher education is increasingly globalized, we recognize that our student body-and even in some cases our educational systems-are no longer just nationally based, but instead are part of a global pool. Teaching Civic Engagement Globally connects teacher-scholars around the world, expanding our options for and understanding of how we can build

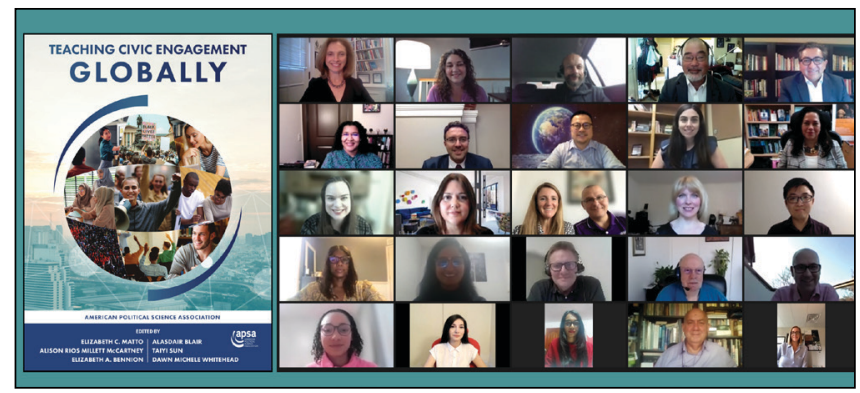

Above: Editor Elizabeth C. Matto (top left) speaks at the zoom webinar for Teaching Civic Engagement Globally alongside other authors and editors of the book. effective civic engagement education and help our democracies to flourish.

Contributors discuss key theoretical discussions and challenges regarding global civic engagement education, highlight successful evidence-based Above: Editor Elizabeth C. Matto at the 2021 pedagogical approaches, and review effective ways to reach across disciplines and the global education community. Most importantly, the book provides tangible steps to link democratic education research with action. With a total of 6 coeditors, 45 authors, and 21 chapters, contributors draw on a range of global experiences that include case studies from Brazil, China, The Gambia, New Zealand, Romania, Russia, and South Africa and demonstrate where institutions in some countries are making progress and rising to these challenges to develop innovative educational models to promote democratic knowledge, skills, values, and experience, whether in democratic, authoritarian, or mixed systems.

Given the global reach of the authors and the ongoing health crisis, an in-person convening to launch the text was not possible. Instead, the editorial team and many of the authors held a virtual conversation on September 14. APSA President Professor John Ishiyama kicked off the conversation with opening remarks stating, "This volume will prove to be an invaluable resource to academics and practitioners everywhere... Training a generation of leaders to participate, organize, and ultimately how to govern."

The text is divided into four sections and each section's editors led short discussions with some of the authors. Section I explores ideas and developments relating to civic engagement education through a number of case studies which include collaborative linkages between local, national, international, and intergovernmental organizations. A portion of this conversation explored the challenges associated with teaching democracy in less liberal contexts with Professor Taiyi Sun discussing importing civic education into authoritarian China and Professors Catherine Shea Sanger and Wei Lit Yew shared their experiences teaching in Singapore.

Section II presents examples of teaching practices around the world that illustrate in a practical way what has worked and not worked, as well as charting areas for improvement. In the virtual conversation, Professors Dmitry Lanko and Gerardo Berthin offered models of teaching civic engagement in less democratic contexts (Russia, Brazil, and Guatemala) while Professors Theodore Chadjipadelis and Georgia Panagiotidou shared research on the effects of peer to peer teaching in Greece.

Section III looks at the teaching of civic engagement education through the lens of country case studies, including examples of civ- 
ic engagement centers, study abroad programs, and co-curricular initiatives. Participants in the webinar who shared their work on creating institutions for civic engagement education included Professors Abraham Goldberg and Carah Ong Whaley from James Madison University, Professor Suzanne Chod from North Central College, Professor Nicole Webster from Pennsylvania State University, and South African Professors Lawrence Piper from the University of the Western Cape and Sondre Bailey from the NGO Gender Dynamix.

Finally, section IV sets out key global issues and challenges in moving civic engagement education forward and identifies necessary pathways for future work. For the webinar, Professor Niina Meriläinen from Finland shared her research on gaps in civic education that leave out students in vocational schools. From Mauritius,

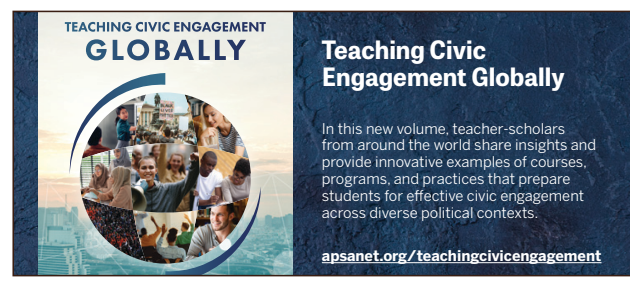

Professors Shantal Kaurooa and Sheetal Sheena Sookrajowa shared a vignette from their country of the deleterious effects when developing democracies don't include civic education in their national curriculum. Serving in an advisory role for this text, Professor Dick Simpson has been instrumental in the publications of all of the teaching civic engagement texts. He offered a concluding call to action in the text and webinar urging the adoption of a global agenda for teaching democracy.

The editorial team of Teaching Civic Engagement Globally includes Elizabeth C. Matto, Alison Rios Millett McCartney, Elizabeth A. Bennion, Alasdair Blair, Taiyi Sun, and Dawn Whitehead. All three texts are available for free on APSA's Teaching Civic Engagement microsite (http://web.apsanet.org/teachingcivicengagement/). In addition to the textbooks, the website houses supplementary materials to the texts, such as syllabi and assessment models, as well as other helpful resources on teaching civic engagement including the library of the Political Science Educator (http://web.apsanet.org/ teachingcivicengagement/political-science-educator/). A recording of the webinar can be found at this link: https://youtu.be/smkOivmSCMQ..

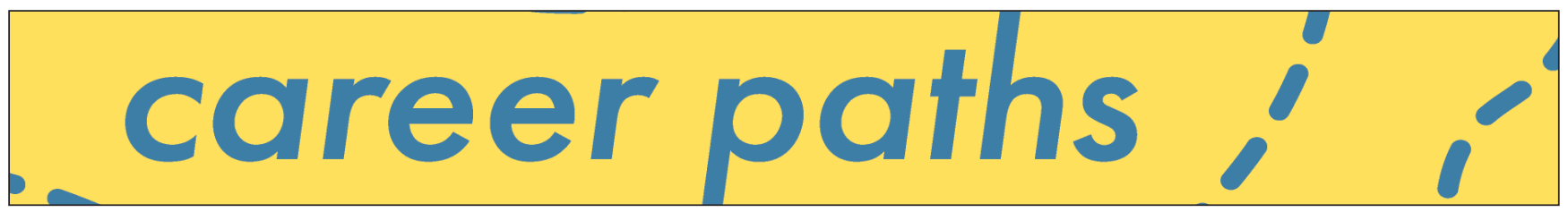

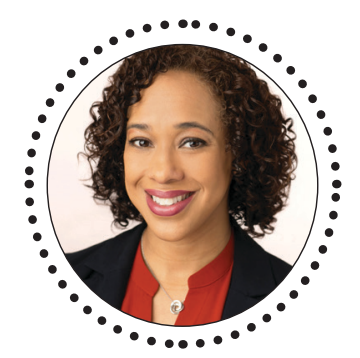

Ashley Brown is a Principal at ghSMART. Drawn to helping leaders thrive, Ashley's career has spanned the private, public, and social sectors. Prior to joining ghSMART,

Ashley was an integrative consultant at McKinsey \&

Company before shiffing into professional development with the firm. She also spent time in people operations at Google, academic administration at the University of Michigan, and was an analyst in the US Intelligence Community. Ashley graduated Phi Beta Kappa and summa cum laude from Spelman College with a degree in Economics. She completed a joint PhD in Public Policy and Political Science at the University of Michigan. Ashley lives in Baltimore with her husband, two children, and their dog.

\section{What kind of work do you do with your organization? What ener- gizes you about your career?}

I'm a leadership consultant at ghSMART. I work with CEOs, senior executives, and investors on leadership assessment, coaching and development, and organizational effectiveness. The most energizing part of my career is that I get to see the human side of inspiring, accomplished people who are driving change in the world. I hear the stories of what shaped them.

\section{What did you study in graduate school? Can you talk a bit about your research?}

I studied American Politics and Public Policy. My dissertation explored how local elected officials developed and leveraged their social capital with a focus on the impact of identity politics.

\section{Why and when did you choose to pursue a non-faculty career?}

When I was an analyst in the Intelligence Community, everyone on my team had a PhD in Political Science, Public Policy, or History. After I decided to resign from the IC, I briefly considered the faculty track. While I loved the academic rigor and relative intellectual autonomy of the professoriate, I never found my purpose or calling in academic research. I wanted clear expectations, and I wanted my impact on the world to be tangible. I also missed working in teams toward a common, defined goal. Candidly, the geographic flexibility and compensation in the corporate space were also appealing as I was making my final decisions.

\section{In what ways did your doctoral training help you in your career?}

My analysis and critical thinking skills were significantly sharpened during my doctoral training. My undergrad degree and the first few years of my $\mathrm{PhD}$ were heavily quantitative; however, much of my dissertation research was qualitative. Being able to distill transcripts into thematic, fact-based data for my clients increases my accuracy and credibility, as well as their confidence.

\section{Do you have any advice for PhD students considering a career in your specific sector?}

Use your time during your doctoral training to learn more about yourself-when are you most energized? What inspires you? What drains you? When are you at your best? As a consultant-and as a grad studentit's easy to get lost in other people's expectations of you. Being true to yourself will be the surest way to succeed in whatever sector you pursue.

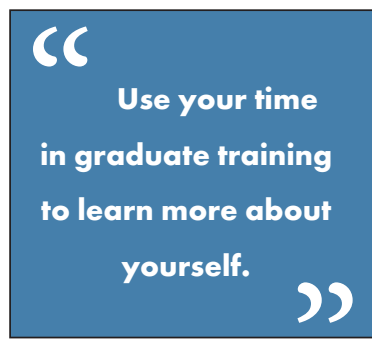

